Cartwright, S. F. \& Thorne, H. V. (1959). J. gen. Microbiol. 20, 61-77

\title{
Some Applications of Detergents to the Study of the Virus of Foot-and-Mouth Disease
}

\author{
By SHEILA F. CARTWRIGHT AND H. V. THORNE
}

The Research Institute (Animal Virus Diseases), Pirbright, Surrey

SUMMARY: The virus of foot-and-mouth disease is highly resistant to the detergents sodium dodecyl sulphate (SDS), cetyl trimethyl ammonium bromide (CTAB) and Tween 80. Results are recorded which show the possibilities of using SDS in the extraction of virus from infected cells, in concentrating virus by elution from adsorbents, and in increasing yields in the filtration and ultracentrifugation of virus suspensions.

Since the work of Burnet \& Lush (1940), who found that the viruses of herpes, louping ill, influenza, myxomatosis, psittacosis and vaccinia were inactivated by anionic detergents, there have been few investigations of the effect of synthetic detergents on animal viruses. Only two viruses appear to have been added to those above, those of lymphocytic choriomeningitis (Stock \& Francis, 1943) and the Rous sarcoma (Guerritore, 1957, 1958), both also inactivated by anionic and cationic detergents. One of the present authors (H.V.T.) and Miss J. Rogers have observed that the virus of vesicular stomatitis is inactivated by anionic and cationic detergents (unpublished).

Studies of the action of bile salts, naturally-occurring detergents, however, show that inactivation is by no means general. Galloway (1931) obtained results which indicated that the virus of foot-and-mouth disease resisted the action of sodium deoxycholate at concentrations up to $10 \%(\mathrm{w} / \mathrm{v})$, and Theiler (1957) showed that although all the arthropod-borne viruses he tested were inactivated by a 1/1000 dilution of this salt, strains of the viruses of poliomyelitis, encephalomyelitis, Coxsackie disease and encephalomyocarditis were resistant at this concentration.

It is shown in the present paper that the virus of foot-and-mouth disease is highly resistant to at least three synthetic detergents, one anionic (sodium dodecyl sulphate) one cationic (cetyl trimethylammonium bromide) and one non-ionic (Tween 80). In addition, some ways are presented in which the resistance to sodium dodecyl sulphate may be exploited in studies of the virus. These might also be of use in the study of other resistant viruses.

\section{METHODS}

Virus strains. In most of the work a Ven. 1 Vallée 0 type virus strain originally recovered from an outbreak of the disease in Venezuela in 1950, twice passaged in cattle and subsequently in tissue culture of cattle tongue epithelium was used. The virus suspensions used were of the 125th to 160 th passages. For some experiments strains from different sources which had been passaged 
in cattle, guinea-pigs, mice, eggs and monolayer cultures of pig kidney cells were used.

Virus suspensions. The method used to prepare suspensions of Ven. 1 culture virus was similar to that described by Cartwright, Pay \& Henderson (1957). Fragments of tongue epithelial tissue were infected with seed virus and incubated at $37^{\circ}$ in sealed flasks containing an atmosphere of $95 \%(\mathrm{v} / \mathrm{v})$ oxygen $+5 \%(\mathrm{v} / \mathrm{v}) \mathrm{CO}_{2}$, in a medium ( $15 \mathrm{ml} . / \mathrm{g}$. tissue) consisting of Tyrode's solution, $0.5 \%(\mathrm{w} / \mathrm{v})$ lactalbumin hydrolysate, $200 \mathrm{mg}$. dihydrostreptomycin sulphate/ml., 200 units benzylpenicillin (sodium salt) $/ \mathrm{ml}$. and $0.001 \%(\mathrm{w} / \mathrm{v}$ ) phenol red. After 18 to $24 \mathrm{hr}$. the culture liquid, subsequently referred to as supernatant virus suspension, was separated from the infected tissue by centrifugation. Virus filtrates of higher titre, used in most experiments and subsequently referred to as ground tissue suspensions, were prepared by grinding the tissue with carborundum powder and extracting with $2 \cdot 5-10 \mathrm{ml}$.

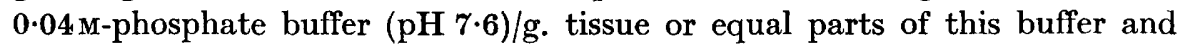
Hartley's broth (Hartley's broth + phosphate) and filtering through Seitz EK pads.

The M. 11 culture virus suspensions were the supernatant fluids from infected pig kidney monolayers clarified by centrifugation for $15 \mathrm{~min}$. at $3000 \mathrm{rev} . / \mathrm{min}$.

Suspensions of the Ven.1 cattle and guinea-pig strains, the M.11 mouse strain and the Rho. 1 strain were prepared by suspending the ground infected tissues in phosphate-buffered Hartley's broth and filtering through Seitz EK pads.

Preparation of cell suspensions. Suspensions of cattle tongue epithelial cells were prepared by digestion of fragments of tongue epithelium with trypsin as described by Cartwright et al. (1957). Pig kidney cells were grown as monolayers in Pyrex glass bottles (Sellers, 1955) and cell suspensions were obtained by washing once with phosphate-buffered saline $(\mathrm{pH} 7 \cdot 6)$, followed by treatment with $1 / 5000$ di-sodium versenate in the same medium for $30 \mathrm{~min}$. at $37^{\circ}$. The cells were deposited by centrifugation at $1000 \mathrm{rev} . / \mathrm{min}$ for $5 \mathrm{~min}$. washed with phosphate-buffered saline and finally resuspended in Tyrode's solution containing $0.5 \%(\mathrm{w} / \mathrm{v})$ lactalbumin hydrolysate.

Preparation of monolayers of tongue epithelial cells. The monolayers were grown in $10 \mathrm{ml}$. screw-capped neutral glass bottles from suspensions of epithelial cells as described by Pay (1957).

Titration of virus suspensions. Serial tenfold dilutions were prepared in 0.04 M-phosphate buffer $(\mathrm{pH} 7 \cdot 6)$ and inoculated intra-peritoneally into groups of five or ten unweaned mice, using a 0.04 ml. dose (Skinner, 1951). The virus content expressed as ID 50/ml. was obtained from the $50 \%$ endpoint dilution calculated by the method of Spearman-Kärber (Kärber, 1931). This method gives easier calculations and is more amenable to statistical treatment (Finney, 1952) than that of Reed \& Muench (1938). The end-points resulting from the use of these two methods differed by less than $0 \cdot 1 \mathrm{log}$ unit.

The results of titrations of 4.5 infective filtrates used in the course of the work were analysed and gave standard errors of $\log _{10} \mathrm{ID} 50 / \mathrm{ml}$. calculated by the method of Irwin \& Cheeseman (1939), ranging from $0 \cdot 17$ to $0 \cdot 4$ for 
5 mice/dilution and from $0 \cdot 14$ to $0 \cdot 27$ for 10 mice/dilution, with mean standard errors of $0 \cdot 27$ and $0 \cdot 19$, respectively. An experiment in which 12 separate titrations of a single filtrate using 5 mice/dilution were performed gave a standard deviation of $\mathbf{0 \cdot 2 2}$, in agreement with the estimate derived above from a single titration.

In comparing the titres of virus suspensions the difference between the titres of two virus suspensions was considered significant when it equalled or exceeded twice the standard error of the difference.

Detergents. The following detergents supplied by L. Light and Co., Ltd. were used: sodium dodecyl sulphate (SDS), cetyl trimethylammonium bromide (CTAB), Tween 80. The SDS was recrystallized twice from ethanol and extracted with ether and the CTAB was recrystallized twice from acetone although the products as supplied gave indistinguishable results from the purified substances when tested in parallel experiments. All detergents were dissolved in $0 \cdot 04 \mathrm{M}$-phosphate buffer $(\mathrm{pH} \mathrm{7 \cdot 6}$ ) for use; concentrations throughout are expressed as $\%(\mathrm{w} / \mathrm{v})$.

Adsorbents. The adsorbents used were Attaclay (a magnesium silicate clay Attapulgite, Attapulgus Co., Ltd., U.S.A.), Celite (Snowfloss, Johns-Manville Co. Ltd.), aluminium hydroxide gel (Alhydrogel Dansk Svovlsyre-og Superphosphat-Fabrik, Copenhagen) and calcium phosphate gel prepared by adding $0 \cdot 3 \mathrm{M}-\mathrm{CaCl}_{2} 6 \mathrm{H}_{2} \mathrm{O}$ to $0 \cdot 2 \mathrm{M}-\mathrm{Na}_{3} \mathrm{PO}_{4} \cdot 12 \mathrm{H}_{2} \mathrm{O}$ followed by washing with distilled water until free from chloride.

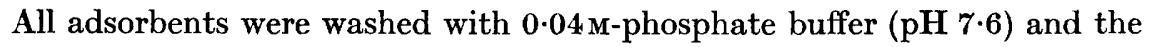
excess was removed by centrifugation before addition of virus suspension. The mixture was allowed to stand, with occasional shaking, for $30 \mathrm{~min}$. or longer at $4^{\circ}$, before centrifugation to separate the adsorbent from the liquid.

Protein determination. In some experiments rough estimates of the protein concentration of the solutions were obtained by measurements of the ultraviolet (u.v.) absorption of the sample, diluted when necessary, at $280 \mathrm{~m} \mu$, with corrections for media containing lactalbumin hydrolysate or Hartley's broth, by using a Beckmann model DU spectrometer with $1 \mathrm{~cm}$. cells. The optical density (o.D.) was not related to actual protein content because of the heterogenous nature of the material.

Detergent determination. Concentrations of SDS and CTAB were estimated by the method of Barr, Oliver \& Stubbings (1948) with bromo phenol blue as indicator.

\section{RESULTS}

\section{Resistance of the virus of foot-and-mouth disease to $S D S, C T A B$ and Tween 80}

SDS. The effect of SDS on the Ven. 1, Dutch 0/1957, Kenya 3/57 tongue epithelial tissue culture strains, an M. 11 pig kidney culture strain and on a Rho. 1 egg strain (Pan 37) in short periods of treatment at $25^{\circ}$ and $37^{\circ}$ was investigated. The filtrates were diluted $1 / 10$ in solutions of SDS of $0 \cdot 05-5 \cdot 0 \%$ concentration to decrease loss of SDS through binding by non-viral material. No significant decrease in titre was found with any of the strains tested up to 
90 min. Experiments over a much longer period (Table 1) with strain Ven. 1 filtrates diluted $1 / 1000$ in detergent solutions of concentration $0 \cdot 1-5 \cdot 0 \%$ at $25^{\circ}$ showed that even after $48 \mathrm{hr}$. there was no significant change in infectivity. Serum neutralization tests showed that no change of type specificity occurred, indicating that the virus was antigenically unchanged.

Table 1. The action of sodium dodecyl sulphate (SDS) on the Ven.1 strain at $\mathbf{2 5}^{\circ}$

\begin{tabular}{|c|c|c|c|c|}
\hline \multicolumn{5}{|c|}{ SDS concentration ( $\%$ ) } \\
\hline $0 \cdot 0$ & $0 \cdot 1$ & $1 \cdot 0$ & $\mathbf{2 \cdot 0}$ & $5 \cdot 0$ \\
\hline \multicolumn{5}{|c|}{ Virus titre $(\log \mathrm{ID50} / \mathrm{ml})}$. \\
\hline $5 \cdot 1$ & - & - & - & - \\
\hline $4 \cdot 9$ & $4 \cdot 1$ & $\mathbf{5} \cdot \mathbf{3}$ & $5 \cdot 5$ & $5 \cdot 3$ \\
\hline $4 \cdot 9$ & - & $4 \cdot 9$ & $5 \cdot 1$ & $4 \cdot 7$ \\
\hline $4 \cdot 7$ & - & 4.9 & $4 \cdot 9$ & 4.9 \\
\hline
\end{tabular}

$C T A B$. Similar results were obtained with CTAB. No significant decrease in titre was found up to $120 \mathrm{~min}$. with any of the strains tested (a Ven. 1 cattle strain, the M.11 pig kidney culture strain and the Rho. 1 egg strain (Pan 37)), and up to $20 \mathrm{hr}$. with the Ven. 1 tissue culture strain (Table 2) with concentrations of $0.05-1.0 \% \mathrm{CTAB}$ at $25^{\circ}$. In tissue culture filtrates precipitation occurred at a detergent concentration of about $0.05 \%$, with the removal of about $25 \%$ of the total u.v. absorption but of less than $1.0 \%$ of the infectivity estimated by titration of the resuspended precipitate.

Tween 80. A few experiments with Tween 80 (non-ionic detergent) gave similar results to the ionic detergents. No decrease in titre was found at $1 \%$ concentration for times up to $20 \mathrm{hr}$. (Table 3).

Table 2. The action of cetyl trimethylammonium bromide (CT AB) on the Ven. 1 strain at $25^{\circ}$

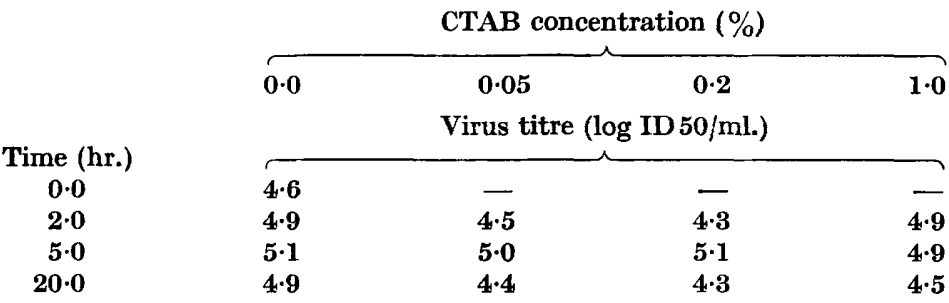

Table 3. The action of Tween 80 on the Ven. 1 strain at $25^{\circ}$

\begin{tabular}{|c|c|}
\hline 0.0 & 1.0 \\
\hline \multicolumn{2}{|c|}{ Virus titre $(\log 1050 / \mathrm{ml}$.) } \\
\hline 5.0 & $4 \cdot 8$ \\
\hline $4 \cdot 6$ & $5 \cdot 3$ \\
\hline $4 \cdot 9$ & $5 \cdot 3$ \\
\hline
\end{tabular}




\section{Extraction of virus from infected cell suspensions}

Suspensions of tongue epithelial and pig kidney cells were infected with strain Ven. 1 virus, washed with antiserum to remove extracellular virus, and resuspended in Tyrode's $+0.5 \%$ lactalbumin hydrolysate with $c .10^{6}$ cells $/ \mathrm{ml}$. as described by Cartwright et al. (1957). The cell suspensions were incubated at $37^{\circ}$ and samples of the whole culture were taken at intervals during the latent and release periods. One portion of each sample was titrated to determine the total infectivity and $1.0 \mathrm{ml}$. was centrifuged at $1000 \mathrm{rev} . / \mathrm{min}$., for $5 \mathrm{~min}$., the supernatant fluid removed and titrated, and the deposited cells treated with $1.0 \mathrm{ml}$. of a solution of SDS for $10 \mathrm{~min}$. This suspension was centrifuged at $3000 \mathrm{rev} . / \mathrm{min}$. for $15 \mathrm{~min}$. and the supernatant fluid titrated.

Table 4. The extraction of virus from infected cell suspensions

$\begin{array}{cccc}\text { Extracting medium } & \text { Whole } & \text { Supernatant } & \text { Extracted } \\ \text { virus }\end{array}$

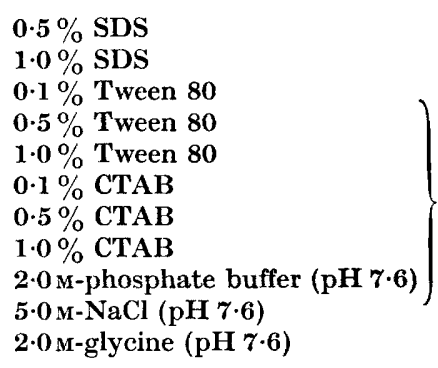

\begin{tabular}{|c|c|c|}
\hline \multicolumn{3}{|c|}{ Virus titre $(\log$ ID $50 / \mathrm{ml})}$. \\
\hline $5 \cdot 0$ & $1 \cdot 7$ & $4 \cdot 8$ \\
\hline \multirow[t]{4}{*}{$5 \cdot 4$} & $2 \cdot 0$ & $5 \cdot 3$ \\
\hline & & $\mathbf{2 \cdot 2}$ \\
\hline & & $2 \cdot 7$ \\
\hline & & $\leqslant 2 \cdot 1$ \\
\hline \multirow{4}{*}{$5 \cdot 1$} & 2.2 & $\mathbf{3 \cdot 5}$ \\
\hline & 28 & $\begin{array}{l}3 \cdot 9 \\
3 \cdot 6\end{array}$ \\
\hline & & $<1.9$ \\
\hline & & $<2 \cdot 7$ \\
\hline 4.5 & $<1 \cdot 4$ & $\leqslant \mathbf{3} \cdot \mathbf{0}$ \\
\hline
\end{tabular}

$0.1 \%$ SDS
$0.5 \%$ SDS
$1.0 \%$ SDS
$0.1 \%$ Tween 80
$0.5 \%$ Tween 80
$1.0 \%$ Tween 80
$1.0 \%$ CTAB
$0.5 \%$ CTAB
$1.0 \%$ CTAB
$2 \cdot 0 \mathrm{M}-$ phosphate buffer $(\mathrm{pH} 7 \cdot 6)$
$5.0 \mathrm{MNaCl}(\mathrm{pH} 7 \cdot 6)$
$2 \cdot 0 \mathrm{M}-\mathrm{glycine}(\mathrm{pH} \mathrm{7 \cdot 6)}$

Pig kidney cell suspensions $2 \mathrm{hr}$. after infection

The recovery of infectivity at different stages of multiplication is shown in Tables 4 and 5. Virus was extracted from infected cells in approximate equivalence to the total virus content and depended in amount on the stage of multiplication reached at the time of sampling. Although some extraction occurred with $0.05 \%$ SDS, a concentration of $0.5 \%$ was necessary to effect complete extraction.

None of the following reagents: phosphate, saline, glycine, CTAB, Tween 80 , extracted more than about $10 \%$ of the total virus from intact infected cells. 
Table 5. Extraction of virus with $0.5 \%$ SDS from pig kidney cell suspensions throughout the growth cycle

\begin{tabular}{|c|c|c|c|}
\hline \multirow[t]{2}{*}{ Time (hr.) } & $\begin{array}{l}\text { Whole } \\
\text { culture }\end{array}$ & $\begin{array}{l}\text { Supernatant } \\
\text { fluid }\end{array}$ & $\begin{array}{l}\text { Extracted } \\
\text { virus }\end{array}$ \\
\hline & \multicolumn{3}{|c|}{ Virus titre $(\log \mathrm{ID} 50 / \mathrm{ml})}$. \\
\hline 1.5 & $5 \cdot 1$ & $2 \cdot 1$ & 4.9 \\
\hline 2.5 & $4 \cdot 3$ & 2.7 & 4.7 \\
\hline $\mathbf{3} \cdot 0$ & 5.7 & $5 \cdot 3$ & $6 \cdot 3$ \\
\hline 4.0 & $7 \cdot 3$ & $\geqslant 6.7$ & $\geqslant 7.5$ \\
\hline $5 \cdot 0$ & $\geqslant 8.3$ & 6.7 & $\geqslant 7.9$ \\
\hline
\end{tabular}

The extraction of virus from infected cells during the latent period by SDS was of particular interest in view of the results of Cartwright et al. (1957) who found that, on the average, less than $1 \%$ of the total virus content was extracted with $0 \cdot 04 \mathrm{M}$-phosphate buffer $(\mathrm{pH} 7 \cdot 6)$ after grinding with abrasives. On extracting ground cell debris with $0.5 \%$ SDS titres equal to those of the whole culture were obtained. Since the completion of the work recorded in this paper this virus has been further investigated (Cartwright \& Thorne, 1958) and has been shown to be cell-associated virus, resistant to the action of antiserum, but without apparent influence in virus multiplication.

\section{Extraction of virus from infected cell monolayers}

Monolayers of tongue epithelial cells were infected and washed as described for cell suspensions. At selected intervals the supernatant fluid was removed and replaced by an equal volume of $0.5 \%$ SDS. After $5 \mathrm{~min}$. this was removed and any suspended cells and debris deposited by centrifugation. Five cultures were used for each time investigated and the liquids were pooled for titration. The results in Table 6 show the increase in virus content with time, and the high ratio of cellular virus-titre to the titre of the virus normally released into the medium.

Table 6. Extraction of virus with $0.5 \%$ SDS from tongue epithelial cell monolayers throughout the growth cycle

\begin{tabular}{|c|c|c|}
\hline \multirow[t]{2}{*}{ Time (hr.) } & $\begin{array}{l}\text { Supernatant } \\
\text { fluid }\end{array}$ & $\begin{array}{l}\text { Extracted } \\
\text { virus }\end{array}$ \\
\hline & \multicolumn{2}{|c|}{ Virus titre $(\log$ ID 50/ml.) } \\
\hline $1 \cdot 5$ & $<0.5$ & $\mathbf{2 \cdot 5}$ \\
\hline $\mathbf{2 \cdot 0}$ & $1 \cdot 8$ & $2 \cdot 9$ \\
\hline $\mathbf{3 \cdot 0}$ & $\leqslant 1 \cdot 3$ & $\geqslant 5 \cdot 7$ \\
\hline $3 \cdot 5$ & $3 \cdot 9$ & $\geqslant 6.3$ \\
\hline $4 \cdot 0$ & $4 \cdot 3$ & $\geqslant 6.9$ \\
\hline
\end{tabular}

Extraction from infected tissue fragments

The possibility of extending this method to the extraction of virus from tissue fragments used in the production of virus by the method of Frenkel (1947, 1953) was investigated. In these experiments extraction for $30 \mathrm{~min}$. at $87^{\circ}$ 
with 10-25 ml. 1-2\% SDS solution/g. tissue gave titres of 7.5-8.5 log ID 50/ml. which differed by less than $\pm \mathbf{0 \cdot 4}$ log unit from those obtained by grinding with carborundum. These extracts were clear solutions readily separable by centrifugation from the tissue fragments.

\section{Effects of SDS and CTAB on cells}

In the presence of SDS at concentrations $0 \cdot 5-1 \cdot 0 \%$ microscopic examination showed that tongue epithelial cells were stained in a few seconds with eosin, indicating cell death (Schrek, 1936); after about 30 sec. marked changes in the appearance of the cells occurred, indicative of cell-wall damage, with the presence in the surrounding fluid of intertwined fibrillar structures, probably of aggregated cytoplasmic material. In suspensions of cells this material and the cell debris aggregated rapidly to form a gelatinous precipitate. Similar effects were observed in pig kidney cells but the cells became completely disrupted with none of the original structure remaining. CTAB in the same concentration range produced staining of tongue epithelial cells by eosin, and in a small proportion of both tongue and pig kidney cells, cytoplasmic protrusions but no extensive disintegration. Tween $80(1.0 \%)$ produced no microscopically observable effects in the structures of either type of cell. Solutions of 2.0 M-phosphate, $5 \cdot 0 \mathrm{M}-\mathrm{NaCl}$ and $2 \cdot 0 \mathrm{M}$-glycine ( $\mathrm{pH} \mathrm{7 \cdot 6)}$ ) caused crenation of the cells, presumably due to osmosis, but no disintegration. These observations indicate that the higher recovery of virus from cells by using SDS, compared with the other solutions tested, was due primarily to its disruptive action on the cells and not to an elution mechanism dependent on electrical charge.

\section{The elution of strain Ven. 1 tissue culture virus from some adsorbents by SDS}

The investigations have been mainly concerned with the efficiency of elution of strain Ven. 1 tissue culture virus by SDS as compared with other agents, with particular reference to the possibility of concentrating the virus by elution in small volume. The adsorbent Attaclay was used for most of this work, but in some experiments the elution of virus from Celite, calcium phosphate gel and aluminium hydroxide gel was studied. Attaclay was used by Hiatt, Rothstein \& Yager (1951) and by Breese \& Briefs (1953) to decrease the protein concentration of chick embryo and mouse brain suspensions, in studies of Japanese encephalitis virus and Coxsackie virus, respectively. In both of these studies it was possible, because of the high protein level, to adsorb the greater part of the protein without decreasing the virus titre of the suspensions.

Adsorption. To provide a safeguard against the possibility of inactivation being interpreted as adsorption, the degree of adsorption was determined by the titration of both the adsorbent and the supernatant fluid. In the case of Attaclay it was demonstrated by centrifugation of infective suspensions and titration of the supernatant fluids that complete elution occurred on dilution to $1 / 1000$ in $0 \cdot 04 \mathrm{M}$-phosphate buffer $(\mathrm{pH} \mathrm{7 \cdot 6})$. Since the virus filtrates used had titres greater than $10^{6} \mathrm{ID} 50 / \mathrm{ml}$. complete elution would occur in the 
dilutions inoculated and titration of the adsorbent would be expected to give a true estimate of the quantity of adsorbed virus.

All of these adsorbents removed virus from strain Ven. 1 tissue culture fluids to the extent of Attaclay shown in Table 7. The amount of virus adsorbed, given by the 'adsorbent titre', was within the limits of error of titration, in agreement with the amount calculated from the difference in titre between that of the original filtrate and the final supernatant fluid. Although precise estimation of the amount of virus adsorbed was not possible, owing to the inaccuracy of the titration method, it is apparent that a correlation exists

Table 7. The adsorption of virus by Attaclay

\begin{tabular}{|c|c|c|c|c|c|}
\hline & $\begin{array}{c}\text { Adsorbent } \\
\text { concentration } \\
\text { (mg./ml.) }\end{array}$ & $\begin{array}{l}\text { Initial } \\
\text { virus } \\
\text { titre }\end{array}$ & $\begin{array}{c}\text { Adsorbent } \\
\text { titre }\end{array}$ & $\begin{array}{c}\text { Supernatant } \\
\text { fluid } \\
\text { titre }\end{array}$ & $\begin{array}{c}\text { Unadsorbed } \\
\text { virus } \\
(\%)\end{array}$ \\
\hline $\begin{array}{c}\text { Ground tissue } \\
\text { suspensions (g./ml.) }\end{array}$ & & & titre (log ID & o/ml.) & \\
\hline $1 / 5$ & 10 & $8 \cdot 7$ & $6 \cdot 9$ & $8 \cdot 2$ & 34 \\
\hline $1 / 5$ & 25 & $8 \cdot 7$ & $8 \cdot 3$ & $7 \cdot 1$ & 2 \\
\hline $1 / 5$ & 50 & $8 \cdot 7$ & $8 \cdot 6$ & $6 \cdot 7$ & 1 \\
\hline $1 / 2 \cdot 5$ & 25 & $7 \cdot 8$ & - & $7 \cdot 0$ & 14 \\
\hline $1 / 2.5$ & 50 & $7 \cdot 8$ & - & $6 \cdot 1$ & 2 \\
\hline $\begin{array}{c}\text { Supernatant } \\
\text { virus suspensions }\end{array}$ & $\begin{array}{l}10 \\
16 \\
50\end{array}$ & $\begin{array}{l}7 \cdot 1 \\
7 \cdot 7 \\
7 \cdot 8\end{array}$ & $\begin{array}{l}6.5 \\
- \\
-\end{array}$ & $\begin{array}{l}6 \cdot 8 \\
5 \cdot 1 \\
4 \cdot 1\end{array}$ & $\begin{array}{c}50 \\
1 \\
<0 \cdot 1\end{array}$ \\
\hline
\end{tabular}

between the quantity of virus adsorbed and the amount of adsorbent used. Fifty mg. Attaclay $/ \mathrm{ml}$. were adequate to adsorb more than $95 \%$ of the virus from ground tissue filtrates of tissue strength $1 / 10$ to $1 / 2 \cdot 5$. From 50 to $80 \%$ of the virus was adsorbed by $25 \mathrm{mg}$. Attaclay $/ \mathrm{ml}$., with only slight adsorption by $10 \mathrm{mg} . / \mathrm{ml}$. Sedimented volumes of the other adsorbents roughly equal to that of Attaclay adsorbed $95 \%$ or more of the virus from ground tissue filtrates. This amounted to $50 \mathrm{mg}$. Celite $/ \mathrm{ml}$., $25 \mathrm{mg}$. calcium phosphate $/ \mathrm{ml}$., expressed as dry weight, and $7 \cdot 5 \mathrm{mg}$. aluminium hydroxide/ml., expressed as $\mathrm{Al}_{2} \mathrm{O}_{3}$.

Ultraviolet absorption measurements of virus suspension, filtered through Attaclay deposited as a thin layer on filter-paper in a Buchner funnel, indicated that adsorption of u.v. absorbing material and virus ran parallel and that no significant adsorption of virus occurred after saturation of the adsorbent with the other constituents of the medium. With both types of virus suspension a much greater proportion of virus than of u.v.-absorbing material was adsorbed. In an experiment with ground tissue virus of titre $10^{8} \mathrm{ID} \mathrm{50} / \mathrm{ml}$. and o.D. $4 \cdot 3$ at $280 \mathrm{~m} \mu$, filtered through $1 \cdot 0 \mathrm{~g}$. of adsorbent, successive $20 \mathrm{ml}$. volumes of filtrate had titres of $10^{6}, 10^{6 \cdot 9}, 10^{7 \cdot 6}, 10^{8}$ and $10^{8} \mathrm{ID} \mathrm{50} / \mathrm{ml}$. with O.D. values of $2 \cdot 45,3 \cdot 16,3 \cdot 8,3 \cdot 85$ and $4 \cdot 0$, respectively; i.e. after the passage of 40-60 ml. adsorption of both virus and u.v.-absorbing material rapidly decreased.

In most cases $10 \mathrm{mg}$. Attaclay/ml. added to tissue culture supernatant fluids was sufficient to adsorb the greater part of the virus. Two experiments in 
which supernatant virus was filtered through Attaclay gave the following

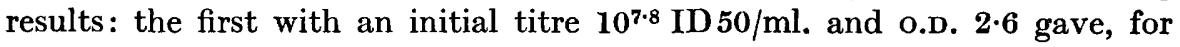
successive volumes of 25,75 and $25 \mathrm{ml}$., titres of $10^{400}, 10^{6 \cdot 6}$ and $10^{6.9} \mathrm{ID} \mathrm{50} / \mathrm{ml}$. and o.D. values of $0 \cdot 1,1.5$ and $1 \cdot 6$ respectively, the second with initial titre $10^{7.8} \mathrm{ID} \mathrm{50} / \mathrm{ml}$. and O.D. $2 \cdot 2$ gave for successive volumes of 70,50 and $50 \mathrm{ml}$. titres of $10^{5.8}, 10^{6.7}$ and $10^{7.5} \mathrm{ID} \mathrm{50} / \mathrm{ml}$, and $0 . \mathrm{D}$. values of $0.3,1.7$ and 1.7 , respectively. These results showed that the treatment of approximately $100 \mathrm{ml}$. of supernatant virus with $1 \mathrm{~g}$. adsorbent resulted in the adsorption of more than $95 \%$ of the virus, followed by an increase in both the titre and optical density of the filtrate. The smaller quantity of Attaclay required for the adsorption of virus from supernatant suspensions is in keeping with the lower protein content as indicated by the optical density.

\section{Elution}

Elution from Attaclay with SDS. Adsorbed virus was eluted from Attaclay by solutions of SDS in amounts increasing with the concentration of SDS (Table 8). A concentration of $0 \cdot 1-0.5 \%$ SDS was found to elute all the adsorbed virus, in a volume equal to that of the original virus suspension at room temperature, in less than $15 \mathrm{~min}$. The concentrations of eluting agents

Table 8. The elution of virus from Attaclay with SDS

\begin{tabular}{|c|c|c|c|c|c|}
\hline \multirow[t]{2}{*}{ SDS (\%) } & $\begin{array}{c}\text { Adsorbent } \\
\text { concentration } \\
\text { (mg./ml.) }\end{array}$ & $\begin{array}{c}\text { Initial } \\
\text { virus } \\
\text { titre }\end{array}$ & $\begin{array}{l}\text { Adsorbent } \\
\text { titre }\end{array}$ & $\begin{array}{l}\text { Eluate } \\
\text { titre }\end{array}$ & $\begin{array}{c}\text { Volume } \\
\text { concentration } \\
\text { factor }\end{array}$ \\
\hline & \multicolumn{5}{|c|}{ Virus titre $(\log$ ID $50 / \mathrm{ml})}$. \\
\hline \multicolumn{6}{|c|}{ Ground tissue suspensions } \\
\hline $0 \cdot 05$ & 50 & $7 \cdot 9$ & $7 \cdot 8$ & $6 \cdot 7$ & 1 \\
\hline $0 \cdot 10$ & 50 & $7 \cdot 9$ & $7 \cdot 8$ & $7 \cdot 9$ & $\mathbf{1}$ \\
\hline $0 \cdot 50$ & 50 & $7 \cdot 8$ & $7 \cdot 8$ & $7 \cdot 5$ & $\mathbf{1}$ \\
\hline $0 \cdot 50$ & 50 & $7 \cdot 5$ & $7 \cdot 4$ & $\leqslant 7 \cdot 3$ & $\mathbf{5}$ \\
\hline $1 \cdot 0^{*}$ & 50 & $\begin{array}{c}8 \cdot 1 \\
(7 \cdot 5-8 \cdot 8)\end{array}$ & $\begin{array}{c}8 \cdot 1 \\
(7 \cdot 4-8 \cdot 7)\end{array}$ & $\begin{array}{c}8 \cdot 7 \\
(7 \cdot 8-9 \cdot 1)\end{array}$ & 5 \\
\hline $1 \cdot 0$ & 25 & $7 \cdot 8$ & $7 \cdot 7$ & $\mathbf{9} \cdot \mathbf{1}$ & 10 \\
\hline \multicolumn{6}{|c|}{ Supernatant suspensions } \\
\hline $1 \cdot 0$ & 20 & $7 \cdot 4$ & $7 \cdot 1$ & $8 \cdot 0$ & 8 \\
\hline $\mathbf{2 \cdot 0}$ & 10 & $6 \cdot 2$ & $6 \cdot 0$ & $7 \cdot 3$ & 20 \\
\hline
\end{tabular}

given throughout refer to the concentration of the solution added. In practice the effective concentration is lowered by the liquid adhering to the adsorbent (2 ml./g.). In the case of elution in $1 / 5$ of the original volume the effective concentration is approximately half of the nominal concentration. To obtain concentration with respect to the original virus, i.e. elution in a smaller volume than the initial one, higher concentrations of SDS were required. For these experiments $1.0 \mathrm{ml}$. of the eluting agent was added to $500 \mathrm{mg}$. adsorbent, when $50 \mathrm{mg}$. adsorbent were used/ml. virus suspension. Because of the liquid held by the adsorbent this gave only a five-fold volume concentration factor. 
The mean log difference in titre between original virus and concentrate for 8 experiments with $1 \cdot 0 \%$ SDS was $0 \cdot 6$ (range $0 \cdot 3-1 \cdot 1$ ) compared to the expected $0.7(\log 5)$. In some cases volume concentration factors of 10- and 20 -fold were obtained by using 25 and $10 \mathrm{mg}$. adsorbent $/ \mathrm{ml}$. with the virus from ground tissue and supernatant fluids respectively, and $c$. 10-fold concentration of virus was found in these experiments.

Ultraviolet absorption measurements of the concentrates showed that the o.D. value at $280 \mathrm{~m} \mu$ increased with increasing detergent concentration and in parallel with increasing degree of virus elution. The greater part of the protein remained adsorbed, giving eluates of the same order of optical density as the original suspension and hence with a higher ratio of titre to protein concentration.

Elution from Attaclay with other media. The efficiency of SDS as an eluting agent was compared with that of various solutions buffered at $\mathrm{pH} 7 \cdot 6$. Neither CTAB nor Tween 80 at concentrations up to $1.0 \%$ eluted virus in quantities in excess of $5 \%$ of that adsorbed. Similar results were obtained with glycerol $(20-100 \%, v / v)$ which was found by Rushchits (1954) to be effective in eluting the virus of foot and-mouth disease from calcium sulphate. Glycine at concentrations greater than $1.5 \mathrm{M}$ eluted the greater part of the adsorbed virus; concentration of virus was achieved, but with a recovery of only $30 \%$. Solutions of $1.0 \mathrm{M}-\mathrm{NaCl}$ eluted only $10-25 \%$ of the virus and this decreased markedly when concentration of the virus was attempted at salt concentrations up to 5.0 M. Almost complete elution was achieved with phosphate buffers ( $\mathrm{pH} 7 \cdot 6)$ at $0.75-1.25 \mathrm{M}$; at concentrations less than or equal to $0.5 \mathrm{M}$ less than $1 \%$ of the virus was eluted; at concentrations higher than $1.5 \mathrm{M}$, where precipitation of some of the protein of the medium occurred with adsorption of virus, elution was negligible. Only $10-20 \%$ of the virus was recovered when five-fold concentration was attempted with 1.0 M-phosphate buffer ( $\mathrm{pH} 7 \cdot 6$ ), obtained by the addition of $2 \cdot 0 \mathrm{M}$-phosphate to the adsorbent.

Elution from aluminium hydroxide gel, calcium phosphate gel and Celite. Good recoveries of virus were obtained from Celite and aluminium hydroxide with SDS at $0.5 \%$ (Table 9 ). It was expected from the insolubility of calcium dodecyl sulphate that low concentrations of SDS would be ineffective in eluting virus from calcium phosphate gel; however, elution in excess of $10 \%$ occurred with 1.0 and $5.0 \%$ solutions of SDS (Table 9).

Elution of virus from aluminium hydroxide with a degree of concentration comparable to that obtained with SDS occurred with 2.5 and $5 \cdot 0 \mathrm{M}-\mathrm{NaCl}$. Elution from calcium phosphate comparable to that by SDS from Attaclay resulted from the use of phosphate buffers $(\mathrm{pH} \mathrm{7.6)}$ at $0.5-1 \cdot 5 \mathrm{M}$; higher strengths caused precipitation of virus and negligible elution. Concentration was achieved at an effective phosphate concentration of $1.0 \mathrm{M}$. Efficient elution and concentration were also found with $2 \cdot 5$ and 5.0 $\mathrm{M}-\mathrm{NaCl}$. Full recovery of virus from calcium phosphate and aluminium hydroxide resulted from elution with $2 \cdot 0 \mathrm{M}$-glycine in a volume equal to that of the original suspension, but not in a smaller volume. Neither Tween $80(1 \%)$ nor CTAB (1\%) eluted more than $1 \%$ of the virus from these two adsorbents. 
Table 9. Elution of virus with SDS from aluminium hydroxide gel, calcium phosphate gel and Celite

\begin{tabular}{|c|c|c|c|c|}
\hline $\operatorname{SDS}(\%)$ & $\begin{array}{c}\text { Initial } \\
\text { virus } \\
\text { titre }\end{array}$ & $\begin{array}{c}\text { Adsorbent } \\
\text { titre }\end{array}$ & $\begin{array}{c}\text { Eluate } \\
\text { titre }\end{array}$ & $\begin{array}{c}\text { Volume } \\
\text { concentration } \\
\text { factor }\end{array}$ \\
\hline & \multicolumn{3}{|c|}{ Virus titre $(\log \mathrm{ID50} / \mathrm{ml})}$. & \\
\hline \multicolumn{5}{|c|}{ Aluminium hydroxide gel } \\
\hline 0.5 & $8 \cdot 2$ & $7 \cdot 9$ & $7 \cdot 9$ & 1 \\
\hline $\mathbf{2 \cdot 0}$ & $8 \cdot 2$ & $8 \cdot 0$ & $8 \cdot 5$ & $\mathbf{5}$ \\
\hline \multicolumn{5}{|c|}{ Calcium phosphate gel } \\
\hline 0.5 & $7 \cdot 5$ & $7 \cdot 1$ & $\leqslant 5 \cdot 7$ & $\mathbf{1}$ \\
\hline $1 \cdot 0$ & $8 \cdot 3$ & $7 \cdot 6$ & $7 \cdot 7$ & $\mathbf{1}$ \\
\hline $5 \cdot 0$ & $7 \cdot 6$ & $7 \cdot 8$ & $7 \cdot 7$ & 1 \\
\hline Celite & $8 \cdot 3$ & $7 \cdot 6$ & $\mathbf{8 \cdot 3}$ & 5 \\
\hline $1 \cdot 0$ & $8 \cdot 5$ & $8 \cdot 5$ & $8 \cdot 7$ & 1 \\
\hline
\end{tabular}

The use of SDS in the filtration of virus suspensions

A difficulty sometimes experienced with the virus of foot-and-mouth disease is the loss by adsorption on filtration through Seitz EK sterilizing pads. This is particularly severe with the suspensions of low protein content from tissue culture. SDS was used in an attempt to diminish these losses.

Ven. 1 strain suspensions from ground tissue were diluted 1/50 in proteinfree media, Hartley's broth + phosphate, amino-Tyrode's solution or Tyrode's solution $+0.5 \%(\mathrm{w} / \mathrm{v})$ lactalbumin hydrolysate, to provide conditions of low protein concentration and thus to increase loss of virus. Ten $\mathrm{ml}$. portions were filtered with negative pressure through Seitz EK pads first treated with

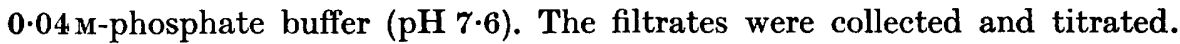
Only when the medium contained lactalbumin hydrolysate was the recovery of virus greater than $0 \cdot 1 \%$ of the original. The results in Table 10 demonstrate

Table 10. The use of SDS in the filtration of Ven.1 strain virus suspensions

Suspension medium

$\operatorname{SDS}(\%)$

$\begin{array}{ccc}\text { Initial } & \text { Filtrate } & \text { Eluted } \\ \text { virus titre } & \text { titre } & \text { titre }\end{array}$

Virus titre $(\log$ ID 50/ml.)

Detergent passed through filter after virus suspension

\begin{tabular}{|c|c|c|c|c|}
\hline Hartley's broth + phosphate & $0 \cdot 1$ & $6 \cdot 4$ & $2 \cdot 9$ & $5 \cdot 7$ \\
\hline Amino-Tyrode's & $0 \cdot 5$ & $7 \cdot 3$ & $\leqslant 2 \cdot 9$ & $\mathbf{5} \cdot \mathbf{5}$ \\
\hline Lactalbumin hydrolysate & $0 \cdot 5$ & $6 \cdot 5$ & $5 \cdot 7$ & $6 \cdot 8$ \\
\hline \multicolumn{5}{|c|}{ Detergent mixed with virus suspension to be filtered } \\
\hline Hartley's broth + phosphate & $0 \cdot 1$ & $6 \cdot 4$ & $5 \cdot 4$ & - \\
\hline Amino-Tyrode's & $0 \cdot 5$ & $7 \cdot 0$ & $6 \cdot 9$ & - \\
\hline
\end{tabular}

the improvement in titre, in many cases 1000-fold, when SDS was included in the suspensions to be filtered or when a solution of this detergent was passed through the filter after the passage of the virus suspension. Failure 
to recover virus completely in some of the experiments can probably be explained in the first method by the adsorption of SDS by the protein of the medium with a consequent decrease in the effective elution concentration, and in the second by the speed of elution which probably also determined the recovery. In both cases higher concentrations of detergent improved recoveries. Only a small recovery resulted from using glycine and no recovery was obtained when CTAB was used in place of SDS. These results were in accordance with those already given concerning elution by these two reagents.

Experiments with undiluted M.11 tissue culture virus (in a medium consisting of Earle's saline, yeast extract and lactalbumin hydrolysate) gave similar results to those with Ven. 1 virus. Virus in this medium has been found (Mr R. F. Sellers, private communication) to be particularly susceptible to losses through adsorption. The recovery of M. 11 virus from mouse tissue was increased 10-50-fold by the use of SDS.

\section{The use of SDS in the centrifugation of virus suspensions}

Although ultracentrifugation is a convenient method of concentrating the virus from volumes less than $c .1 \mathrm{l}$., the recoveries are usually only of the order of $30-50 \%$ (Dr C. J. Bradish, private communication). It appeared probable that losses occurred through adsorption of virus on large particle aggregates produced by deposition and discarded in the normal clarification cycle. The practicability of using SDS rather than 0.04M-phosphate buffer ( $\mathrm{pH} 7 \cdot 6$ ), the normal suspending medium, was therefore investigated. Ven. 1 strain tissue culture virus was passaged in guinea-pigs and a phosphate-buffer extract of the ground pads clarified by centrifugation to provide starting material. This was centrifuged at $35,000 \mathrm{rev} . / \mathrm{min}$. for $50 \mathrm{~min}$. in a Spinco L 40 rotor to sediment the virus (Bradish, Brooksby, Dillon \& Norambuena, 1952). The deposited pellets were suspended in a small volume of $0.04 \mathrm{M}$ -

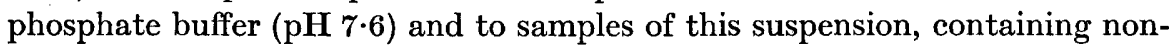
dispersed aggregates of cell debris of a microsomal character, solutions of SDS, glycine and sodium chloride were added to give a three-fold volume concentration factor. After $30 \mathrm{~min}$, at room temperature the suspensions were clarified (3000 rev./min. for $1 \mathrm{hr}$.) and the supernatant fluids removed for titration. A similar experiment with Ven. 1 tissue-culture virus, using a 12-fold concentration factor, gave much smaller deposits than guinea-pig virus. The results of a typical guinea-pig virus experiment (Table 11) demonstrate the superiority of $1 \%$ SDS over the other solutions used. The recovery from tissue culture suspensions, although greatest with SDS was also good with the other solutions probably because of the small size of the deposit.

\section{Removal of SDS}

In many problems the presence of SDS in virus suspensions is undesirable (e.g. in seed virus for tissue culture), therefore methods for its removal are required. Dialysis, electro-dialysis and deposition of the virus by centrifugation should be readily applicable, without infectivity loss, to small volumes. Several other methods have been investigated. 
(1) A single extraction with an equal volume of butanol decreased the concentration of SDS in extracts and concentrates from about $1.0 \%$ to less than $0.02 \%$ without loss of virus, and appears to be a suitable and rapid means for use with small volumes, particularly when it is desirable to decrease the protein concentration at the same time.

Table 11. The recovery of virus from centrifuged deposits

\begin{tabular}{|c|c|c|}
\hline & $\begin{array}{c}\text { Ven. } 1 \\
\text { guinea-pig } \\
\text { strain }\end{array}$ & $\begin{array}{l}\text { Ven.1 T.C. } \\
\text { strain }\end{array}$ \\
\hline & \multicolumn{2}{|c|}{ Virus titre (log ID 50/ml.) } \\
\hline Titre of original virus suspension & $6 \cdot 6$ & $8 \cdot 0$ \\
\hline Titre of deposit & $7 \cdot 2$ & $9 \cdot 1$ \\
\hline & \multicolumn{2}{|c|}{ Supernatant from clarification } \\
\hline $\begin{array}{l}\text { Suspending medium } \\
0 \cdot 04 \mathrm{~m} \text {-phosphate buffer }(\mathrm{pH} 7 \cdot 6)\end{array}$ & $6 \cdot 6$ & $8 \cdot 8$ \\
\hline $0.1 \%$ SDS & $6 \cdot 5$ & $8 \cdot 8$ \\
\hline $1.0 \% \mathrm{SDS}$ & $7 \cdot 3$ & $9 \cdot 2$ \\
\hline $1 \cdot 0 \mathrm{M}$-glycine & $6 \cdot 4$ & $8 \cdot 8$ \\
\hline $0.5 \mathrm{M}-\mathrm{NaCl}$ & $6 \cdot 4$ & $8 \cdot 8$ \\
\hline
\end{tabular}

(2) Cooling to $0-4^{\circ}$ and removal of the precipitated SDS by filtration or centrifugation has been found to decrease SDS concentrations of the order of $\mathbf{1 . 0} \%$ to about $0.2 \%$.

(3) Concentrations less than $0.5 \%$ SDS were decreased to zero by the addition of CTAB in an amount sufficient to precipitate all SDS without loss of virus. Removal of quantities of SDS greater than $\mathbf{1 . 0} \%$ incurred loss of virus by adsorption on the precipitate. This procedure has the advantage that the exact quantity of CTAB necessary can be determined by titration of a sample by the method of Barr et al. (1948).

(4) The precipitation of SDS as the insoluble barium salt caused loss of virus by adsorption.

Methods (2) and (3) used in conjunction with one another would seem to be the most suitable, so far investigated, for use with large volumes of virus suspensions.

\section{DISCUSSION}

Resistance to detergents might be a general property of the virus of foot-andmouth disease, independent of its source and type, since the strains tested had been passaged in a variety of hosts, cattle, guinea pigs, mice, eggs or in tissue culture. The resistance to ionic detergents enables some tentative conclusions to be reached about the structure of the virus. In the first place this resistance, considered along with the long established resistance of the virus to the lipid-extracting solvents ether, acetone, ethanol (e.g. Pyl, 1951) and to butanol, suggests that the virus contains no lipid, at least in its outer structure. (It is possibly significant that at least two of the viruses found to be inactivated by SDS by Burnet \& Lush (1940), namely influenza and vaccinia, contain lipid; there may be a general correlation between susceptibility to solvents and to detergents whether synthetic or natural.) Further, since 
detergents denature proteins primarily by disruption of hydrogen bonds and salt linkages, it is possible that linkages of this type do not play a significant role in the structure of the protein of the virus of foot-and-mouth disease. If linkages of protein to nucleic acid occur, these would be expected to be of a co-valent rather than electro-valent character.

The ease and rapidity with which the virus of foot-and-mouth disease can be extracted from the cells by SDS, together with the instantaneous cessation of multiplication, indicates the use that may be made of this reagent in studies of virus multiplication. The total virus content of cells may be estimated when it is impracticable or inconvenient to extract the virus by grinding, for example, from single cells or monolayers. Further, the removal of monolayers from glass by treatment with trypsin or di-sodium versenate is unnecessary, thus decreasing the risk of loss of virus.

The elution of virus from Attaclay in high dilutions of phosphate buffer suggests that in the experiments of Cartwright et al. (1957), the virus from the cell debris fraction was probably free at the dilutions used and not bound in any special manner as suggested by these authors. The elution of virus by SDS does not give direct evidence on this point since extensive cell damage occurs and any linkage of a special kind would probably be broken. However, the close correspondence of the titres of the SDS extracts and ground cells indicates that the dissociation of these bonds yields virus which does not differ in infectivity from the normal. Hence there seems to be no particular reason for assuming that the virus is bound strongly to any cell constituent. It is probable that the low infectivity of phosphate extracts from debris was due to the small volume of buffer used to extract and the high ratio of adsorbent (debris) to virus. The plaque-counting method, however, may reveal differences not apparent from the present work.

Although tissue culture methods have greatly facilitated the production of high titre virus, the titre is still, in general, too low for many purposes without concentration. In recent years methods have been developed for the concentration of polio virus from large volumes of tissue culture fluids (Schwerdt \& Schaffer, 1955) but in this case the very favourable stability properties of the virus have enabled co-precipitation with the proteins of the medium at $\mathrm{pH} 4.0$ 4.5 to be used as an initial concentration step. The extreme lability of the virus of foot-and-mouth disease at low $\mathrm{pH}$ values precludes the use of this method, and the methods at present being used for the concentration of this virus (precipitation with ammonium sulphate, ethanol or acetone after deproteinization with chloroform, Pyl \& Röhrer, 1955; or protamine, Hansen $\&$ Holm, 1950; and ultracentrifugation) although useful for concentration from sources of low volume are not well suited for use on a large scale. It is therefore desirable for this purpose to find a method using either precipitation or adsorption followed by elution. Apart from early reports of elution from adsorbents (Pyl, 1931) before quantitative titration methods were developed, elution of inactivated virus from aluminium hydroxide vaccines with $5 \%$ ammonium phosphate and saturated di-sodium phosphate was reported by Hobohm \& Petermann (1949) and Hobohm, Petermann \& Forrest (1951). 
However, the high $\mathrm{pH}$ value of these reagents would probably be inimical to live virus, and in any case to obtain concentration of virus it was necessary to follow elution by pervaporation and precipitation with ammonium sulphate. The eluting properties of SDS indicate that its use with adsorbents of greater capacity or with virus suspensions of lower protein content should yield useful degrees of concentration. Although solutions of saline and $\mathrm{pH} 7 \cdot 6$ phosphate buffer have been found to produce concentrations of the same order, the lower concentrations of SDS required, together with the ease of its removal, recommend its use.

Since neither CTAB nor Tween 80 was found to be an effective eluting agent it is evident that the eluting property of sodium dodecyl sulphate does not derive directly from its surface activity. Elution probably results from the complexing of SDS with the adsorbed protein and virus to the point when repulsion resulting from the high negative charge breaks the bonds with the adsorbent and releases protein and virus into the liquid. The quantity of SDS required for complete elution would then, as found, depend on the amount of protein adsorbed.

No insurmountable difficulties should arise in the use of SDS in the remaining two applications. When virus is being passaged from one animal host to another, the use of SDS in filtration, possibly following its use in extracting tissue, might well be adopted as a routine procedure which should decrease the number of experimental failures resulting from filtration losses in this type of work. In tissue culture passaging, however, the action of SDS on cells would require that its concentration in the inocula was below a harmful level; there is no doubt that this can be effected. Where virus is to be used for vaccines or for experimental investigations, the procedures can again be of value in reducing losses.

While the greater recoveries obtainable in centrifugation should be of value in complement-fixation and other serological studies actual purification of virus may be impaired by the nature of the elution process. This might result from the dispersion of large particles, normally discarded as aggregates, which might through the action of SDS, persist with virus in subsequent stages. However, it is also possible that the action of SDS would be to dissociate the aggregates to components of low sedimentation constant which would be discarded in the supernatant from deposited virus. Apart from these applications which have been investigated, the antibacterial properties of SDS and CTAB might be of value in work with the virus of foot-and-mouth disease.

We are indebted to Mr R. F. Sellers and Mr H. H. Skinner who supplied some of the virus suspensions, and to Mrs D. M. Balchin and Miss M. Shoobridge for technical assistance.

\section{REFERENCES}

Barr, T., Oliver, J. \& Stubbings, W. V. (1948). The determination of surface active agents in solution. J. Soc. chem. Ind., Lond. 67, 45.

Bradish, C. J., Brooksby, J. B., Dillon, J. F. \& Normabuena, M. (1952). Ultracentrifugal studies of the infective and complement-fixing components in the virus system of foot-and-mouth disease. Proc. Roy. Soc. B, 140, 107. 
Breese, S. S. Jr. \& Briefs, A. (1953). Certain physical properties of Coxsackie strains. Proc. Soc. exp. Biol., N.Y., 83, 119.

Burnet, F. M. \& Lush, D. (1940). The action of certain surface-active agents on viruses. Aust. J. exp. Biol. med. Sci. 18, 14.1.

Cartwright, S. F., Pay, T. W. F. \& Henderson, W. M. (1957). Multiplication of the virus of foot-and-mouth disease in culture. J. gen. Microbiol. 16, 730.

Cartwright, S. F. \& Thorne, H. V. (1958). The use of two properties of the virus of foot-and-mouth disease in studies of its multiplication. Nature, Lond. 182, 717.

Finney, D. J. (1952). Statistical method in biological assay. London: Charles Griffin and Co. Ltd.

Frenkel, H. S. (1947). La culture du virus de la fièvre aphteuse sur l'epithélium de la langue des bovidés. Bull Off. int. Epiz. 28, 155.

Frenkel, H. S. (1953). Research on foot-and-mouth disease; the cultivation of the virus on a practical scale on explantations of bovine tongue epithelium. Bull. Off. int. Epiz. 39, 91.

Galloway, I. A. (1931). Action of sodium taurocholate, sodium glycocholate and sodium desoxycholate on the virus of foot-and-mouth disease. 4th Progress Report, Foot-and-Mouth Disease Committee (1931) Appendix 3, p. 313, London: H.M.S.O.

Guerritore, D. (1957). Die Inaktivierung des Rous-Sarkoms mittels eines kationischen Detergens. Z. Krebsforsch. 61, 649.

GuERritore, D. (1958). Reversibility of the inactivation of Rous Sarcoma extracts by detergents. Nature, Lond. 181, 419.

Hansen, A. \& Holm, P. (1950). Combination of foot-and-mouth disease virus, albumen and protamine. Acta path. microbiol. scand. 27, 882.

Hratt, G. W., Rothstein, N. \& Yager, R. H. (1951). An adsorption technique for the partial purification of Japanese encephalitis virus in chick embryo tissue suspensions. Proc. Soc. exp. Biol., N.Y. 78, 703.

Новонм, K. O. \& PetermanN, H. G. (1949). Concentration and demonstration of the complement-fixing antigen in foot-and-mouth disease vaccine type Riems. Gac. vet., B. Aires 11, 56.

Новонм, K. O., Petermann, H. G. \& Forrest, G. E. (1951). Elution and demonstration of the complement-fixing antigen in adsorbed foot-and-mouth disease vaccines. Gac. vet., B. Aires $13,163$.

Irwin, J. O. \& Chesseman, E. A. (1939). On an approximate method of determining the median effective dose and its error in the case of a quantal response. J. Hyg., Camb. 39, 574.

KärBer, G. (1931). Beitrag zur kollektiven Behandlung pharmakologischer Reihenversuche. Arch. exp. Path. Pharmak. 162, 480.

PAY, T. W. F. (1957). The propagation of the virus of foot-and-mouth disease in monolayer cultures of adult bovine tongue epithelium. Proc. R. Soc. Med. 50, 919.

Pyx, G. (1931). Adsorptionsversuche mit Maul-und-Klauenseuche-Virus in Pufferlösungen. Zbl. Bakt. (1. Abt.), 102, 284.

PyL, G. (1951). Versuche zur Reinigung des neurotrop modifizierten Meerschweinchen-B-Stammes des Maul-und-Klauenseuche-Virus. Exp. Veterinärmed. 4, 9.

Pý, G. \& Röhrer, H. (1955). Méthodes d'extraction et de concentration du virus aphteux. Bull. Off. int. Epiz. 43, 597.

REed, L. T. \& MUEnCh, H. (1938), A simple method of estimating fifty per cent end-points. Amer. J. Hyg. 27, 493.

Rushchits, A. S. (1954). Purification and concentration of foot-and-mouth disease virus from vesicle fluid. Trud. Inst. Vet. Alma-Ata, 6, 190.

Schrex, R. (1936). A method for counting the viable cells in normal and in malignant cell suspensions. Amer. J. Cancer, 28, 389. 
SchwerdT, C. E. \& SchafFer, F. L. (1955). Some physical and chemical properties of purified poliomyelitis virus preparations. Ann. N.Y. Acad. Sci. 61, 740.

Seluers, R. F. (1955). Growth and titration of the viruses of foot-and-mouth disease and vesicular stomatitis in kidney monolayer tissue cultures. Nature, Lond. 176, 547.

SkinNer, H. H. (1951). Propagation of strains of foot-and-mouth disease virus in unweaned white mice. Proc. R. Soc. Med. 44, 1041.

Stock, C. C. \& Francis, T. JR. (1943). The inactivation of lymphocytic choriomeningitis by soaps. J. exp. Med. 77, 323.

Theiler, M. (1957). Action of sodium desoxycholate on arthropod-borne viruses. Proc. Soc. exp. Biol., N.Y. 96, 380.

(Received 30 June 1958) 